\title{
Bajocian transgressive-regressive sequences of the Tecocoyunca Group, southern Mexico, with maximum flooding surfaces marked by Thalassinoides
}

\author{
Grzegorz PIEŃKOWSKI ${ }^{1, *}$, Michelangelo MARTINI² and Mildred ZEPEDA-MARTÍNEZ ${ }^{2}$ \\ 1 Polish Geological Institute - National Research Institute, Rakowiecka 4, 00-975 Warszawa, Poland \\ 2 Universidad Nacional Autónoma de México, Instituto de Geología, México D.F., 04510 Mexico
}

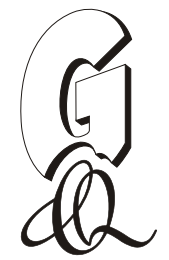

Pieńkowski, G., Martini, M., Zepeda-Martínez. M., 2019. Bajocian transgressive-regressive sequences of the Tecocoyunca Group, southern Mexico, with maximum flooding surfaces marked by Thalassinoides. Geological Quarterly, 63 (3): 449-459, doi: 10.7306/gq.1480

Associate editor: Michał Zatoń

Bajocian (Middle Jurassic) transgressive-regressive sequences (TRS), outcropping in the Rosario Nuevo Creek (Tezoatlán Basin, Tecocoyunca Group) in Oaxaca State, Mexico, represent one of the Jurassic phases of opening and widening of a trans-Pangaean marine corridor (called also the Hispanic Corridor) and show a retrogradational-progradational set of sedimentary successions with decipherable and diverse facies. Two TRSs have been distinguished. The lower one starts with fluvio-deltaic sandstones including pedogenic horizons. Drowning of the deltaic plain and gradual rising of the water table is marked by change in vegetation: from large trees to low-rise vegetation with characteristic clumps of dense roots cemented by siderite. The delta plain succession is topped by a thin coal seam, followed by a transgressive surface. Ensuing laminated mudstones of restricted marine origin pass into open marine deposits, represented by bioturbated heterolithic strata with ammonites followed by nearshore sandstones, deposited in a storm-dominated basin. A similar succession, although without the deltaic part, is repeated in the next TRS. Of note are two thin $(15-20 \mathrm{~cm})$ continuous beds with Thalassinoides isp. networks, present within open marine deposits. Although large Thalassinoides networks are mostly known from shallow-marine and coastal environments, the case from Mexico represents less common occurrences from a deeper marine (offshore) setting, associated with maximum flooding surfaces, sediment starvation and firmgrounds (Glossifungites ichnofacies). Occurrences of Thalassinoides meshes, precisely marking maximum flooding surfaces, are helpful in defining the hierarchy of sequence stratigraphic cycles.

Key words: Mexico, Jurassic, Thalassinoides, maximum flooding surfaces, siliciclastic sequence stratigraphy.

\section{INTRODUCTION}

Available palaeontological and geological evidence suggests the existence of an Early-Middle Jurassic trans-Pangaean marine seaway that connected the eastern Pacific and western Tethyan oceanic realms $\sim 25 \mathrm{~m}$.y. before the birth of the Atlantic Ocean (Hallam, 1983; Smith, 1983; Damborenea, 2000; Aberhan, 2002; Fig. 1A, C). This seaway, called by many authors the Hispanic Corridor (e.g., Smith, 1983), was opened between Late Sinemurian and Pliensbachian time (Aberhan, 2002; Porter et al., 2013), permitting an intermittent biotic interchange between the Pacific and Tethyan oceans before the beginning of Pangea breakup and dispersion (Hallam, 1983; Damborenea, 2000; Aberhan, 2002; Fig. 1A). Despite its relevance in controlling the global oceanic circulation and produc-

\footnotetext{
* Corresponding author, e-mail: grzegorz.pienkowski@pgi.gov.pl
} Received: February 28, 2019; accepted: April 23, 2019; first published online: July 17, 2019 ing major changes in the faunal palaeogeographic distribution during Jurassic time, the evolution of the Hispanic Corridor, from its foundation to its progressive widening, is still not exhaustively defined. This is mostly because the Lower and Middle Jurassic transgressive stratigraphic record exposed in many areas along the inferred trace of the Hispanic Corridor has not been studied in detail. Lower and Middle Jurassic successions exposed in Mexico contain the record of a regional-scale transgressive event that is finely preserved in the Huayacocotla and Tezoatlán areas, in Veracruz and Oaxaca states, respectively (López-Ticha, 1985; Goldhammer, 1999; Ochoa-Camarillo et al., 1999; Fig. 1). Based on their Lower and Middle Jurassic age, some authors interpreted these transgressive successions as the manifestation of widening of the Hispanic Corridor into Mexican territory (Sandoval and Westermann, 1986; Carrasco-Ramírez, 2003). However, sedimentological studies of these successions are few (Erben, 1956a; Ochoa-Camarillo et al., 1999; Carrasco-Ramírez, 2003; Vite-del Ángel, 2014), and are mostly focused on defining the Jurassic stratigraphy and biodiversity of these areas.

In this work, we present new sedimentological data from the Middle Jurassic succession exposed in the Rosario Nuevo 

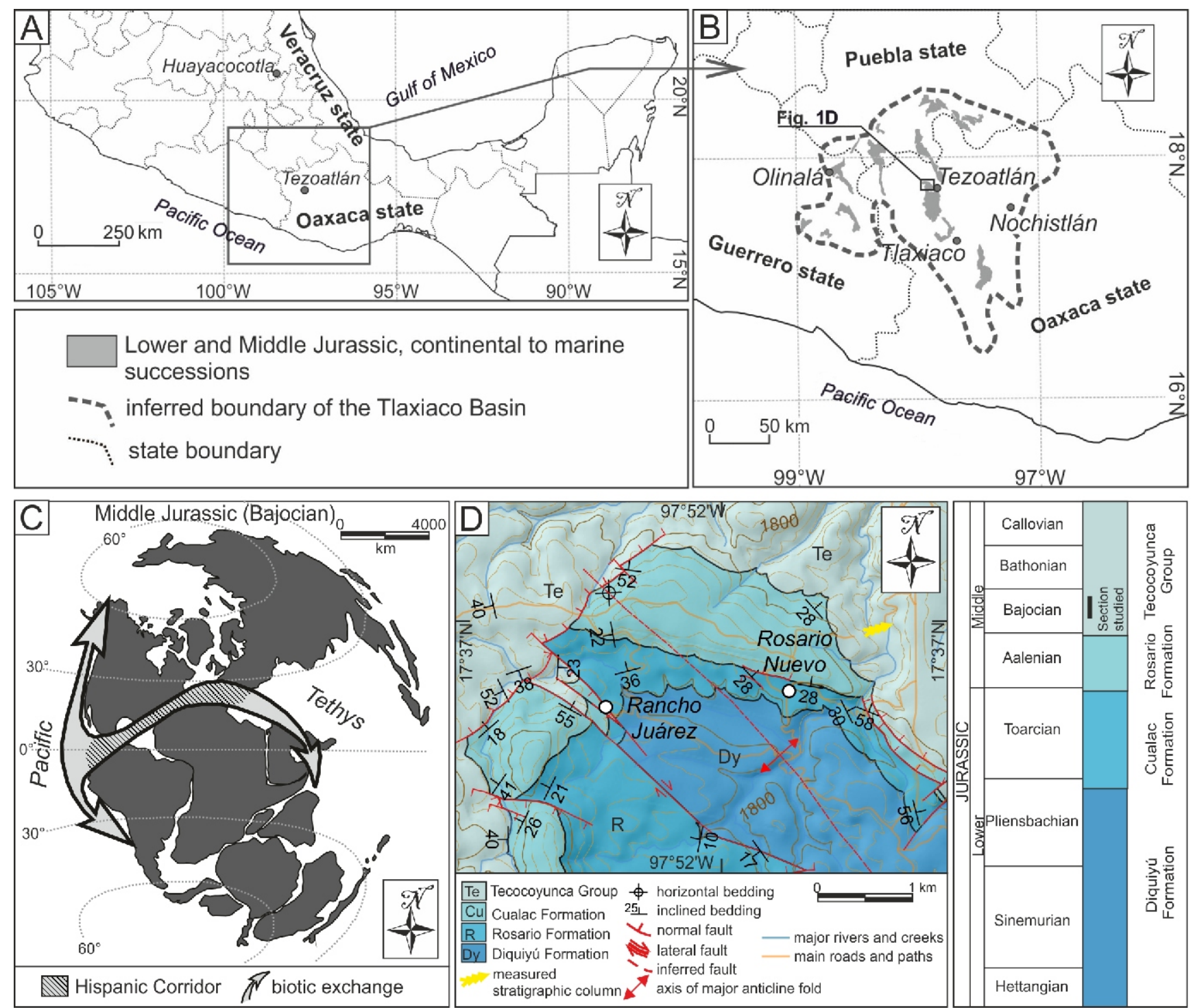

Fig. 1. Locality, palaeogeography and stratigraphy of the area studied

A - geographic map of southern Mexico showing the location of the Huayacocotla and Tezoatlán areas and map showing the location and extension of the Tlaxiaco Basin with Jurassic System outcrops (after López-Ticha, 1985); B - geological outline of the Tezoatlán area showing the extension of the different Jurassic lithostratigraphic intervals, as well as the location of the measured stratigraphic column (after Zepeda-Martínez et al., 2018); C - global-scale Middle Jurassic (Bajocian) palaeogeographical map showing the location of the Hispanic Corridor and the biotic exchange route (after Damborenea, 2000, modified); D - geological map and chronostratigraphic column of the Tezoatlán area (modified by Zepeda-Martínez et al., 2018)

Creek section, Tezoatlán area, southern Mexico. These data contribute to our understanding of the evolution of the sedimentary environment in southern Mexico during the major transgressive event related to the development of the Hispanic Corridor.

\section{GEOLOGICAL SETTING}

The Tezoatlán area is located in the state of Oaxaca, southern Mexico (Fig. 1A). López-Ticha (1985) considered Jurassic rocks of the Tezoatlán area as part of the Tlaxiaco Basin, a $\sim 200 \mathrm{~km}$ wide rift basin that is discontinuously exposed in southern Mexico between Olinalá (Guerrero state) and Nochistlán (Oaxaca state; Fig. 1A, B). In the Tezoatlán area, the Jurassic succession is composed of four main stratigraphic intervals (Fig. 1D) that were informally introduced by Erben (1956a). The oldest interval is represented by felsitic to intermediate volcanic rocks of the Diquiyú Formation (Erben, 1956a; Morán-Zenteno et al., 1993; Fig. 1D). Available U-Pb zircon ages from volcanic rocks of the Diquiyú Formation vary between 197 and 184 Ma (Durán-Aguilar, 2014). The Diquiyú Formation is conformably overlain by alluvial fan deposits of the Rosario and Cualac formations. The Rosario Formation is dominantly sourced from the south by volcanic rocks, whereas alluvial fan deposits of the Cualac Formation were derived from a metamorphic basement high, located directly to the north of the Tezoatlán area (Zepeda-Martínez et al., 2018). This heterogeneous provenance of deposits from the Jurassic succession exposed in the Tezoatlán area has been interpreted by Zepeda-Martínez et al. (2018) as the manifestation of an abrupt topography, which resulted from the exhumation of crustal 
blocks of different composition during the continental attenuation that accompanied Pangea breakup. Alluvial fan deposits of the Cualac Formation are conformably overlain by the Tecocoyunca Group (Fig. 1D). This group consists of a lower part which is composed of flood-plain sandstone, mudstone, metre-thick coal layers with an abundant fossil flora, and an upper part made up of marine sandstone and mudstone (Erben, 1956a; Morán-Zenteno et al., 1993). The age of transgression in the Tezoatlán area is bracketed to Bajocian time by ammonite fossils (Sandoval and Westermann, 1986; Cantú-Chapa, 1998; Mitta, 2018).

\section{LOCATION OF THE STUDY SECTION}

The section studied in this work is located $1 \mathrm{~km}$ to the north-east of the village of Rosario Nuevo, along the Rosario

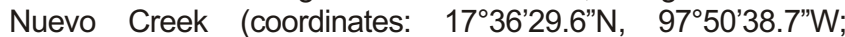
Fig. 1B, D). We selected this section because it is the best exposure in the area, representative of the Middle Jurassic marine transgression represented in the Tecocoyunca Group (Figs. 2-4), that has been visited by many international researchers during different field trips organized in the last 60 years (e.g., Erben, 1956b; Martini et al., 2017). Most of the previous studies were mostly focused on palaeontological finds. However, despite its geological importance, previous authors did not provide a detailed description of the different lithofacies that compose this section and an exhaustive interpretation of the sedimentary environment is lacking. With the aim of improving the reconstruction of the Middle Jurassic transgression in southern Mexico, we measured this continuous section bed-by-bed with a Jacob's staff and described in detail the different facies that make up this transgressive stratigraphic record.

\section{LITHOFACIES DESCRIPTION}

Along the measured section, we recognized 16 stratigraphic intervals that display different sedimentological features. From the base to the top of the section, we named these stratigraphic intervals from $A$ to $P$ (Fig. 2).

Intervals A-D correspond to the lowermost $2 \mathrm{~m}$ of the measured section (Figs. 2 and 3 ) and are composed of medium- to fine-grained, grey to brownish-grey sandstone with thin siltstone/mudstone intercalations. Sedimentary structures are dominated by large-scale trough cross-bedding and planar bedding. In places current ripples are observed. Plant roots are pervasive; horizons with denser and thinner roots occur at the top of each interval. Roots are sediment-filled, and in the upper interval $D$ many of them are coalified. Root traces are particularly dense at the top of interval $D$, where many of them are grouped in characteristic clumps, cemented by siderite (due to weathering, the siderite is widely replaced by Fe oxides; Figs. 3B and $4 A)$. In places, bioturbation appears. There are several peculiar hollows in the interval C (Fig. 3B). On their internal walls one can observe traces of tree linings, indicating that they are hollows after tree trunks. Drifted plant detritus is common throughout intervals $A-D$, particularly at the top of interval $D$.

Interval $\mathbf{E}$ is up to $20 \mathrm{~cm}$ thick (Fig. $3 \mathrm{~A}$ ) and is composed of coal and coaly mudstone. In places yellow sulphur staining is visible, indicating traces of decomposed pyrite.

Interval $\mathbf{F}$ is $\sim 3.5 \mathrm{~m}$ thick (Figs. $3 \mathrm{~A}$ and $4 \mathrm{~B}, \mathrm{C}$ ) and is composed of dark grey to black laminated mudstone with thin silty-sandy laminae (Fig. 4B) and siderite nodules (Fig. 4C).
Some of the nodules are large and contain characteristic cone-in-cone structures. Mudstones are finely laminated; lenticular lamination (where sandy/silty laminae or lenses occurring in mudstone do not show cross-lamination - Fig. 4B, C) is also common.

Interval $\mathbf{G}$ is $\sim 1.8 \mathrm{~m}$ thick (Figs. $3 \mathrm{~A}$ and $4 \mathrm{D}$ ) and is characterized by a variety of cross-lamination resulting from mixed lithologies of sand and mud, termed heterolithic, represented by grey lenticular to wavy heterolithic units (Reineck and Wunderlich, 1968; de Raaf et al., 1977; Schieber, 1999) with thin beds of fine-grained sandstones with hummocky cross-stratification (Harms et al., 1975; Dott and Burgeois, 1982). Siderite bands and nodules are common in the middle part (Fig. 2). The upper (but not the uppermost) part of this interval contains more abundant sandy beds (wavy bedding) with micro-hummocky cross-stratification and planar lamination and is heavily bioturbated with a dominance of Rhizocorallium isp. and Teichichnus isp. (Figs. 2 and 4D). The uppermost part $(\sim 0.15 \mathrm{~m})$ is composed of slightly darker lenticular heterolithic strata with ammonites (Figs. 2, 3A and 4G). The whole interval $G$ (particularly in its uppermost part) contains numerous fossils, mostly bivalves and ammonites, that point to a Bajocian age (Sandoval and Westermann, 1986; Cantú-Chapa, 1998; Martini et al, 2018; Mitta, 2018).

Interval H ( 0.1 $\mathrm{m}$ thick) is a thin, slightly ferruginous layer with epirelief burrows (Fig. 4E, G), sharply inserted between intervals $\mathrm{G}$ and I. The burrows represent a boxwork system composed of horizontal, cylindrical (in places inflated), unlined, branched tunnels forming irregular polygons. The burrows are red and pink stained, smooth-walled and unlined, passively mud-filled, with burrow diameters varying from 3 to $10 \mathrm{~cm}$. Vertical shafts are absent, only few that are inclined were observed. Some tunnels demonstrate local inflations (Fig. 4E). Mudstone preserved between burrows and burrow-infills is similar to the overlying mudstones. The characteristics of these burrows fulfill the definition of Thalassinoides isp. given by Ehrenberg (1944).

Interval I is $4 \mathrm{~m}$ thick (Fig. 2) and is represented by grey lenticular to wavy heterolithic strata with thin beds of fine-grained sandstone with hummocky cross stratification. Bioturbation is moderate to pervasive and progressively decreases upwards. Siderite bands and nodules are common. Interval I is very similar to interval G.

Interval $\mathbf{J}$ is $0.3 \mathrm{~m}$ thick (Fig. 2) and contains laminated, dark grey mudstone with silty-sandy lamina and thin siderite bands. This interval is similar to interval $F$.

Interval K $(\sim 2.5 \mathrm{~m})$ is represented by grey lenticular to wavy heterolithic strata with thin beds of fine-grained sandstones with micro-hummocky cross-lamination. Siderite bands and nodules are common. Interval I is very similar to the intervals $\mathrm{G}$ and I.

Interval L $(\sim 2.7 \mathrm{~m})$ contains fine- to medium-grained sandstones with hummocky and swaley cross-stratification (Fig. 4F). Subordinate flaser bedding was observed, Mudstone occurs as thin and often discontinuous laminae which drape ripple marks and are generally confined to ripple troughs.

Interval M ( $\sim 0.35 \mathrm{~m})$ lies with a sharp contact on interval $\mathrm{L}$. It is similar to intervals $\mathrm{G}, \mathrm{I}$ and $\mathrm{K}$ and is composed of grey lenticular to wavy heterolithic strata with thin beds of fine-grained sandstones with micro-hummocky cross-stratification.

Interval $\mathbf{N}(\sim 0.2 \mathrm{~m})$ is a thin slightly ferruginous, muddy layer, sharply inserted between intervals $\mathrm{M}$ and $\mathrm{O}$, with a dense Thalassinoides isp. network. The interval is similar to interval $\mathrm{H}$. Disarticulated bivalves occur between Thalassinoides burrows.

Interval $\mathbf{O}(\sim 6 \mathrm{~m})$ contains grey lenticular to wavy heterolithis strata with thin beds of fine-grained sandstones with 

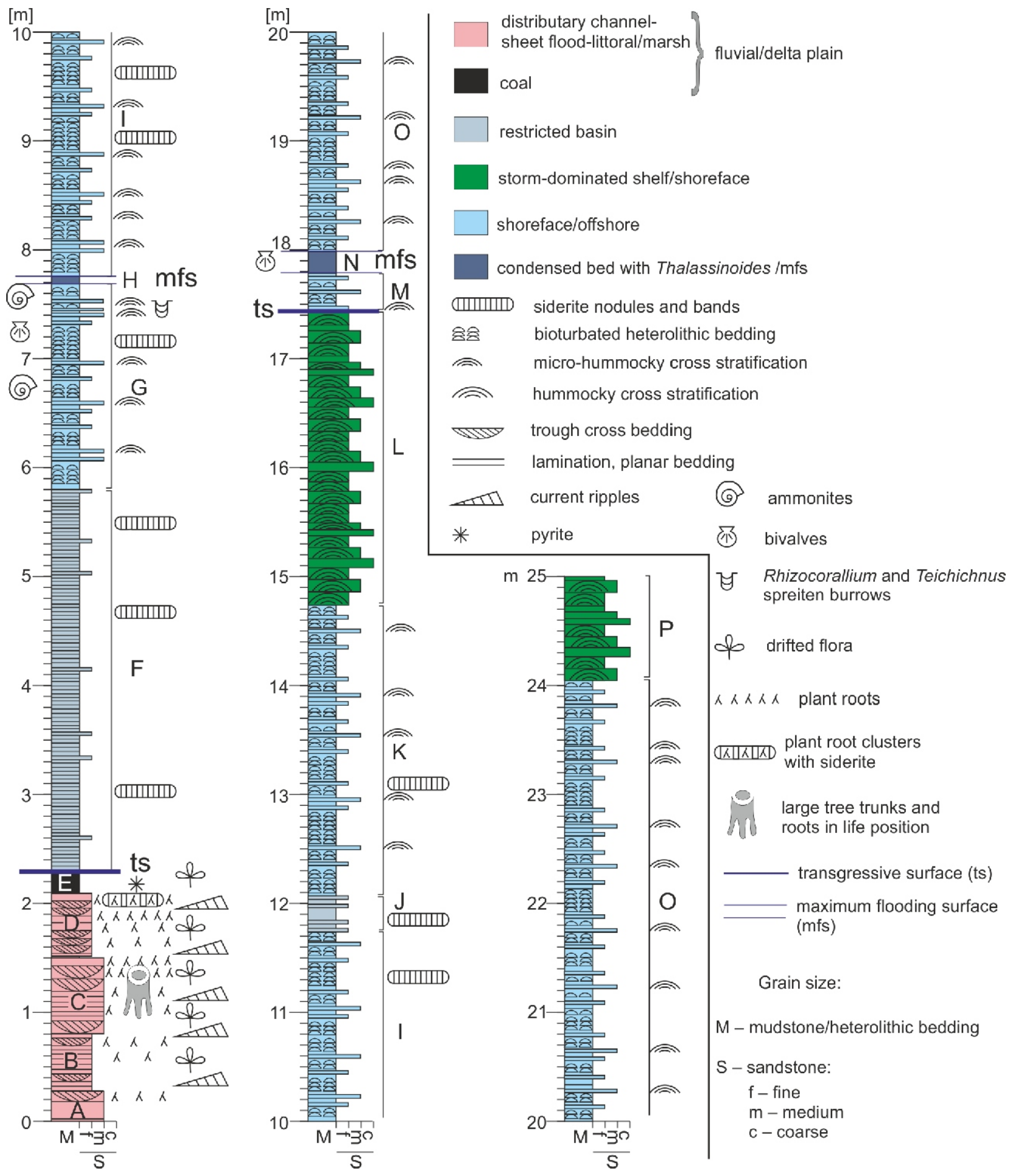

Fig. 2. Rosario Nuevo creek (Tecocoyunca Group) geological profile showing lithological intervals A-P, facies and major bounding surfaces 

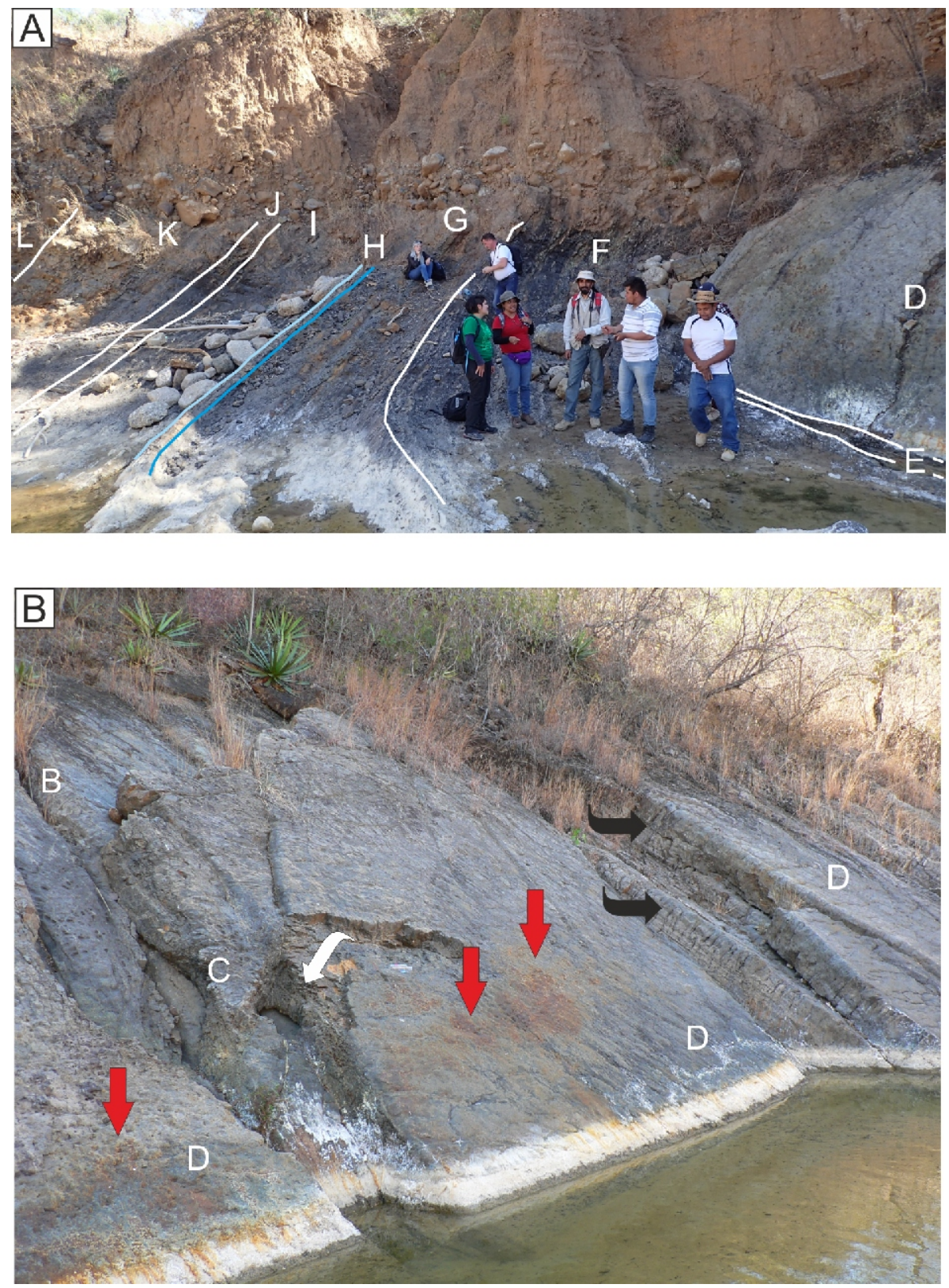

Fig. 3. Rosario Nuevo Creek profile with major lithofacies

A - part of the Rosario Nuevo Creek section showing intervals D-L; Thalassinoides isp. bed is marked by blue lines (for lithological description see Fig. 2); B - intervals B-D (delta plain/estuary facies association), black arrows - plant root horizons, root marks are progressively smaller and shallower upsection, red arrows - subcircular clumps (30 to $50 \mathrm{~cm}$ wide) with dense plant roots and concentrations of iron compounds (formerly siderite), white arrow - hollow after large tree trunk, penetrating interval C (for lithological description see Fig. 2)

hummocky cross-stratification and planar bedding. Bioturbation is moderate. Interval $\mathrm{O}$ is similar to intervals $\mathrm{G}, \mathrm{I}, \mathrm{K}$ and $\mathrm{M}$ - although interval $\mathrm{O}$ does not contain many siderite bands.

Interval $\mathbf{P}(>1 \mathrm{~m})$ contains fine- to medium-grained sandstones with hummocky cross-stratification and is similar to interval L.

\section{DEPOSITIONAL ENVIRONMENTS}

Intervals A-D of the section studied contain mostly sandstones lithofacies (Figs. 2, 3 and 4A) characteristic of fluvial (mostly channel-fill) deposits. Internal structures of different scale observed in the sandstones comprise mainly those of dune migration, producing trough cross-bedding (Fig. 3B) with some planar (horizontal) bedding, the latter produced either by upper flow regime currents or those of lower flow regime. Fine sandstone, siltstone, and locally mudstone (Fig. 4A) were deposited along the margins of the channels as decelerating, suspended-load-rich waters spilled over the banks (Miall, 1996). Individual layers are separated by pedogenic horizons with plant roots. Plant roots may be preserved either as coalified structures, commonly associated also with ferruginous matter (primarily siderite) or as sediment-filled structures, usually with thin coaly linings on the outer surface. These different stages of preservation reflect diagenetic changes in conditions of varying oxygenation the less oxygen in the sediment, the higher chance for "coalified forms" of preservation. In addition, long plant roots preserved in 

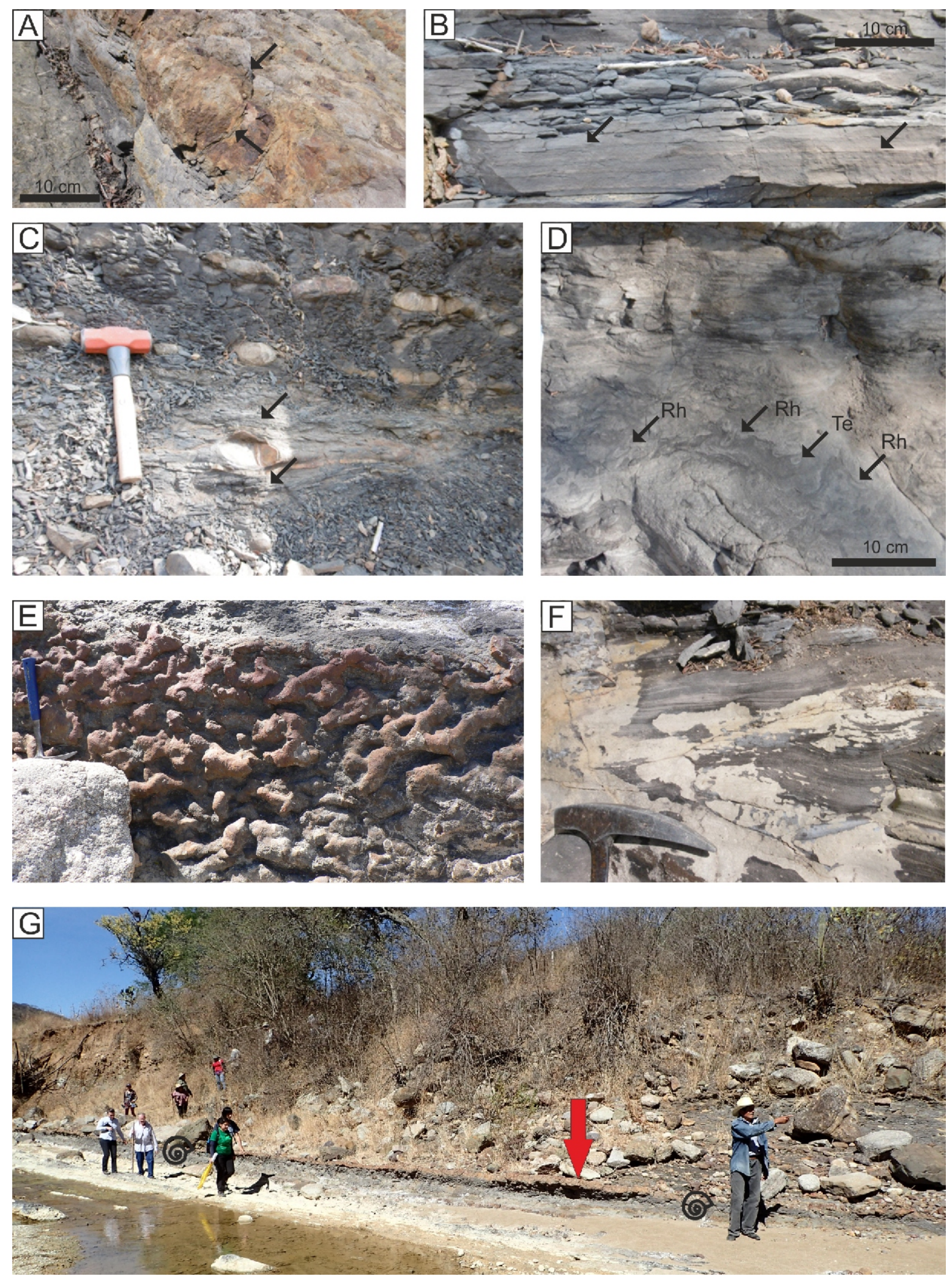

Fig. 4. Lithofacies types of the Rosario Nuevo Creek profile

A - iron-rich cluster with dense and short plant roots, top of interval D, note internal chambers visible inside the roots (arrowed); B lamination in dark grey mudstone, interval F; C - siderite bands and nodular concretions in laminated dark mudstone with silty-sandy laminae (lenticular lamination), interval F; D - bioturbated heterolithic strata with dense Rhizocorallium isp. and Teichichnus isp., upper part of interval "G", ammonites and bivalves are common in this part of the section; $\mathbf{E}$ - interval (bed) $\mathrm{H}$, dense network of Thalassinoides isp. burrows; $\mathbf{F}$ - hummocky- and swaley cross-stratification in fine-grained sandstones, interval L; G - continuous lateral extension of Thalassinoides isp. bed (interval $\mathrm{H}$, arrowed) inserted between between open-marine heterolithic strata of intervals $\mathrm{G}$ and $\mathrm{I}$, symbols of ammonites indicate finds of Parastrenoceras tlaxiacense Ochoterena and Oppelia (Oppelia) subradiata erbeni Westermann (Mitta, 2018) in lenticular heterolithic strata just below the Thalassinoides isp. bed 
the freely drained sandy parent material (Fig. 3B) indicate a lowered water table and more oxygenated soil (Podzol), which is usually associated with coarser sediments (Arndorff, 1993). Short, coalified plant roots (Fig. 4A) were developed in the low relief, poorly drained areas covered with backswamps and marshes (Fig. 3A) and point to a high water table and reducing, often acidic conditions, which is usually associated with more fine-grained sediments and a Gleysol type of palaeosol (Arndorff, 1993). In such a palaeosol, plant roots may develop internal chambers (Fig. 4A) which facilitate gas exchange with the outer environment (Sarjeant, 1975). Overall, the plant roots get smaller and denser upwards (most dense roots occur at the top of interval D). In interval $C$ there are peculiar hollows, interpreted as remnants of large tree trunks in life position. Vertically-oriented tree trunks were preserved in life position and point to well-drained sediment, a relatively lower water table and very rapid deposition. The water table rose significantly during deposition of intervals $D$ and $E$. Vegetation observed in these intervals was dominated by low-rise plants, diminishing in size up the section. In the uppermost part of interval $D$ plant roots are grouped in characteristic clumps (Figs. 3 and 4 A) cemented by ferruginous cement (formerly siderite). Siderite precipitation can be associated with roots (Ludvigson et al., 1998, 2013). Oxygen depletion, in combination with a decrease in sedimentation rate, promoted anoxic diagenetic conditions, favouring abundant siderite precipitation (Fimmen et al., 2008; Bojanowski et al., 2016). Particularly favourable conditions for carbonate cementation occurred when the sediments were covered by swamp deposits. Such clumps probably represent stressed vegetation on intermittently submerged terrain. This would indicate further rise of the water table, consistent with base-level rise during an approaching marine transgression.

The next interval $E$ is represented by coal and coaly mudstone (Fig. $3 \mathrm{~A}$ ), occurring just beneath the transgressive surface and representing a period of diminished siliciclastic sediment supply with somewhat increased accommodation space, allowing development of marshes. The transition from flood plain to marsh could have been additionally caused by enhanced tectonic subsidence in the basin. Formation of raised mires on the coastal plain could have stabilized the shoreline rise for some time, inhibiting transgression and encouraging vertical stacking of facies belts (McCabbe, 1984; Shanley and McCabe, 1993). Pyrite-bearing palaeosols and coals often underlie flooding and transgressive surfaces (Figs. 2 and $3 \mathrm{~A}$ ). This suggests that the pyrite was precipitated due to the introduction of sulphate ions by percolating marine water (Martini and Johnson, 1987; Arndorff, 1993). The same rule related to diagenesis of coal was shown by Postma (1982) and Ketzer et al. (2003). Overall, the whole A-E succession would represent a stage of gradual drowning of a delta plain/estuary associated with diminishing current speed and water-table rise. Succession A-E would then belong to the initial (non-marine) part of a transgressive systems tract (Pieńkowski, 2004), developed below the actual transgressive surface.

Intervals $\mathrm{F}$ and $\mathrm{J}$ are composed of dark grey to black laminated mudstone that we interpret as deposits that are typical of a lagoonal or restricted marine bay origin. The absence of trace fossils, resulting in well-preserved lamination and numerous siderite bands and nodules, point to poorly oxygenated bottom conditions. Oxygen deficiency was likely caused by the restricted character of the basin and enhanced delivery of nutrients, resulting in eutrophication and deposition of organic-rich sediments. A relatively high admixture of iron in the form of siderite nodules and sideritic mudstone beds was probably caused by the proximity of marsh areas that are a prominent source of iron.

Intervals $\mathrm{G}, \mathrm{I}, \mathrm{K}, \mathrm{M}, \mathrm{O}$ (compared to intervals $\mathrm{F}$ and $\mathrm{J}$ ) are the result of a higher energy of waves and currents. The colour of these sedimentary rocks is much paler relative to that of inter- vals $\mathrm{F}$ and $\mathrm{J}$, and in places bioturbation by deposit-feeding organisms is intense, which led to moderate to extensive obliteration of primary sedimentary structures. Cross-lamination resulting from mixed lithologies of sand and mud, called heterolithic strata, implies alternating current flow and slackwater conditions. In most cases cross-lamination is visible in the lenses, forming lenticular bedding or (when cross-laminated sandy intercalations are more frequent and show lateral continuity) wavy bedding (Fig. 4D, F). In most cases, the sandy-silty laminae in the hererolithic units show micro-hummocky cross lamination (Fig. 4D), interpreted as an indication of storm-generated wave action. Bioturbation is common, indicating favourable, well-oxygenated bottom conditions with sufficient nutrient delivery. Sandstone intercalations with erosional bases, graded bedding and micro-hummocky cross-stratification are common, further pointing to storm activity. Of note are occurrences of marine fauna, including bivalves and ammonites. All these intervals are interpreted as deposited in an open shelf basin, where the bottom was affected by heavy storms - most likely in the offshore zone (Handford, 1985; Leckie and Krystynik, 1989; Galloway and Hobday, 1996).

Intervals $L$ and $P$ are composed of fine-grained sandstones with subordinate silty or muddy intercalations (Fig. 2). Most common is hummocky cross-stratification and swaley cross-stratification (Fig. 4F) that point to a storm-dominated nearshore depositional environment. Additionally, planar bedding is also observed (Fig. 2). Planar bedding can be attributed either to low-energy deposition from suspension or, by contrast, such structures can be produced by strong currents (upper flow regime). Lee-side grain avalanching on ripples and dunes with low height/length ratios is not capable of producing well-defined cross-strata, and bedform migration in such cases produces "horizontal" stratification (Smith, 1971). There are no indicators of emergence (i.e. structures characteristic of the beach zone) or shallow shoreface forms, such as sandwaves and dunes produced by onshore-directed or longshore currents. Most likely, these sandstones were deposited in a storm-dominated nearshore zone (deeper shoreface) zone, at the average storm wave base, below the fair-weather wave base with deposition of graded, storm-generated beds - tempestites (Dott and Bourgeois, 1982; Aigner, 1985).

Intervals $\mathrm{H}$ and $\mathrm{N}$ are thin beds with dense networks of Thalassinoides isp. (Fig. 4E, G). Intervals $\mathrm{H}$ and $\mathrm{N}$ show sharp lithological boundaries with the underlying and overlying strata, which indicate an abrupt change in sedimentation rate towards sediment starvation and condensation. Three-dimensional, excellent preservation with no compaction, sharp boundaries, lack of lining and passive infilling point to their formation in a coherent (clayey-silty) compacted firmground. Firmground conditions were associated with early cementation and very slow or no sedimentation. Thalassinoides burrows are generally regarded as dwelling burrows produced by deposit-feeding crustaceans (Decapoda). During their lifetime, these organisms formed a system of hollow tunnels in the middle well-ventilated ichnotier up to $75 \mathrm{~cm}$ deep (Pemberton and MacEachern, 1995; Bromley, 1996; Pemberton et al., 2004; Rodriquez-Tovar et al., 2007), which became passively backfilled with overlying sediments after the organism's death. In a firmground substrate, tracemakers do not need to reinforce their burrows (e.g., Ghibaudo et al., 1996; Sharafi et al., 2012). Thus, these burrows should be discussed in the context of the Glossifungites ichnofacies (Ekdale et al., 1984). The unlined, passively infilled burrows in the Rosario Nuevo Creek section are thought to have been produced during the omission stage, as a result of sediment starvation (Ghibaudo et al., 1996; MacEachern and Burton, 2000; Wetzel and Uchman, 1998). Thalassinoides burrows occur in all the marine and coastal facies (Monaco et al., 2007), but in most publications Thalassinoides finds are men- 
tioned from shallow-water Glossifungites, Cruziana, less commonly from the Skolithos, and occasionally from the Teredolites ichnofacies and it is believed that firmground Thalassinoides characterizes usually diverse environments of coastal areas and shoals. (i.e., Seilacher, 1967; Pemberton and Frey, 1985; Pemberton and MacEachern, 1995) or the shoreface zone (Pervesler et al., 2011). This would imply that Thalassinoides beds in the Rosario Nuevo section of the Tecocoyunca Group would represent extremely rapid shallowing events occurring in open-marine fine-grained facies (Figs. 2 and 4G). However, such a scenario seems to be unlikely because there is no transitional facies below and above the Thalassinoides beds. Moreover, Thalassinoides beds occur within the most distal mudstone facies with ammonites (Fig. 4G). Thus, a more plausible explanation is that these Thalassinoides beds were developed by deep-water condensation/no sedimentation conditions where a deep-water, firmground substrate was colonised by Thalassinoides trace makers. Indeed, Thalassinoides networks (although not as large and shallow as those in the Rosario Nuevo section) have been reported from deep marine condensed beds of New Jersey, USA (Savrda et al., 2001) and from offshore omission (transgressive) flooding surfaces of Miocene age in Italy (Ghibaudo et al., 1996). Open Thalassinoides burrows were also observed in recent firm substrate in the deep South China Sea, in an area receiving very little sediment input (Wetzel, 2008). Thus Thalassinoides beds at the Rosario Nuevo section would represent a rather atypical (low energy and distal) Glossifungites ichnofacies (MacEachern and Burton, 2000; Wetzel and Uchman, 1998), dominated by the shallowly foraging, probing and deposit-feeding/dwelling structures of firmground Thalassinoides, shallowly excavated within a firm substrate. Consequently, we suggest that condensed Thalassinoides beds in the Tecocoyunca Group section were formed in response to sediment starvation induced by maximum transgression.

\section{SEQUENCE STRATIGRAPHY}

The sequence is the primary interval of sequence stratigraphy and can be defined in several ways by bounding unconformities, such as subaerial unconformities - sequence boundaries or their equivalents in the case of depositional sequences or a transgressive-regressive sequence (Vail et al., 1977; Posamentier and Vail, 1988), or maximum flooding surfaces in the case of genetic stratigraphic sequences (Galloway, 1989). In the present paper, the transgressive-regressive sequence (TRS) paradigm (Embry, 2002) is adopted, because of its practicality and usefulness. Sequence stratigraphy provides a useful geological framework for regional correlation of events and sedimentary intervals.

Sedimentation of deltaic intervals A-E (Figs. 2 and 5) was controlled by gradual base-level rise causing water-table rise, diminishing transport energy and a change in the standing veg-

Fig. 5. Sequence stratigraphy of the Rosario Nuevo Creek section with two transgressive-regressive sequences (TRS) shown

Relative sea level curve to the right, d.pl. - delta plain, L-r.b. - restricted basin, s.f. - shoreface, o.s. - offshore; maximum flooding surfaces (Thalassinoides beds) are marked with blue arrow; systems tracts: TST - transgressive systems tract (retrogradation), RST - regressive systems tract (progradation), ts - transgressive surface, $\mathrm{mfs}$ - maximum flooding surface; note overall stepwise development of transgression

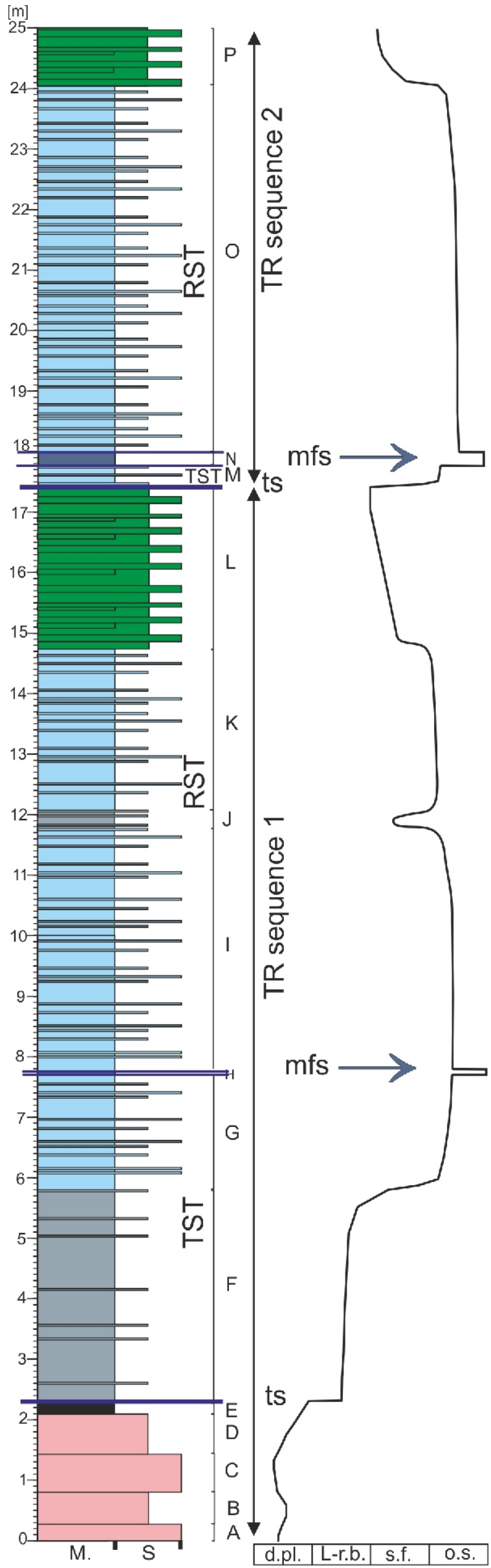


etation. Based on these features, one can regard this succession as an aggradational/retrogradational succession of non-marine deposits below the transgressive surface, belonging to the transgressive systems tract (TST; Pieńkowski, 2004). The sequence boundary, located below the section studied, is not visible in the Rosario Nuevo exposure. A thin coal seam (interval E), located above a pedogenic horizon with characteristic clumpy vegetation and just below the transgressive surface, records a time of very limited clastic sedimentation and rising base level, allowing formation of marshes and accumulation of plant organic matter (Fig. 2). Preservation of coal is dependent on a rising water-table, which itself is best achieved by base level rise (McCabbe and Parrish, 1992). Mires developed under conditions of rising base level may maintain themselves through many thousands of years (Flint et al., 1995). The mire was finally (and quickly) drowned (transgressive surface Fig. 5) and the next stage of the TST is represented by sedimentation of dark, organic-rich mudstone with diagenetic siderite nodules (interval F - Fig. $3 \mathrm{~A}$ ) in a restricted marine (lagoon embayment). This restricted basin opened and transformed into a fully marine basin with sedimentation of marine heterolithic strata (interval $G$ ). The period of maximum flooding, sediment starvation and condensation is marked by a Thalassinoides bed (maximum flooding surface - interval $\mathrm{H}$ Fig. 4F). The maximum flooding surface marks the pivotal moment between rising sea level (transgressive systems tract TST - intervals A-G) and falling sea level (progradation - regressive systems tract $-\mathrm{RST}-$ intervals $\mathrm{I}-\mathrm{L}-\mathrm{Fig}$. 5). The thin interval $\mathrm{J}$ with darker mudstone may indicate transient restriction in the basin associated with eutrophication. Interval L (storm-dominated shoreface zone) marks shallowing of the basin and its top is identified with a sequence boundary, maximum regression and at the same time the transgressive surface of the next sequence, which is connected with sedimentary bypass and omission. The relatively thin interval $\mathrm{M}$ (marine heterolithic beds) would represent the transgressive systems tract of the next TRS with the maximum flooding surface represented by the second condensed Thalassinoides bed (interval $N$ - Fig. 5). Consequently, intervals $O$ and $P$ would represent the progradational stage (RST) of the second TRS. The occurrence of maximum flooding surfaces marked by well-visible veneers of condensed beds with Thalassinoides is helpful in determining the hierarchy of the sea level cycles - as there are two maximum flooding surfaces they represent transgressiveregressive sequences, not parasequences caused by more local fluctuations in the sea level/sedimentary regime.

\section{CONCLUSIONS}

The stratigraphic section measured in the Rosario Nuevo section of the Tecocoyunca Group provides a fine example of step-wise marine transgression on a fluvio-deltaic plain (or estuary) with a well-preserved and diverse facies succession. Of note are changes of facies controlled by base-level and water-table rise with a succession of different types of vegetation from high-rise forest to low-rise mire vegetation. The first TRS shows a very gradual development of retrogradational facies, culminating in a maximum flooding surface marked by a condensed bed with Thalasssinoides. The prograding part of the TRS is terminated by storm-dominated sandy facies of the shoreface zone. The next TRS lacks a deltaic/fluvial component in its lower part, which might point to a general widening and deepening of the marine environment during the later TRS. The second TRS is otherwise similar to the first one, including the presence of a second maximum flooding surface marked by Thalasssinoides, confirming systematic repetition of this correlative horizon. Condensed beds with Thalassinoides at the Rosario Nuevo section were formed in response to sediment starvation induced by maximum transgression and provide a well preserved and relatively uncommon example of deep-water Glossifungites ichnofacies (MacEachern and Burton, 2000; Wetzel, 2008), As deep-water firm-ground surfaces with Thalassinoides are essentially indistinguishable from Thalassinoides - dominated fabrics at shelf sequence boundaries that formed by subaerial exposure or subsequent transgressive ravinement (Savrda et al., 2001) caution must be used in developing a precise sequence stratigraphic interpretation of firmground ichnofabrics - particularly in the absence of broader stratigraphic context. In the case of this well-documented example from Mexico, the firm-substrates with distinctive Thalassinoides networks can be used as a significant tool for recognizing key sequence-stratigraphic surfaces and their hierarchy.

Acknowledgements. We are grateful to P. Leonowicz and A. Wetzel for their valuable comments. This paper is a part of the project financed from statutory resources of the Polish Geological Institute - National Research Institute project 62-9614-1701-00-1 and from the Polish National Science Centre, granted on the basis of decision no. DEC-2012/06/M/ST10/00478. This is a contribution to the ICDP project JET and IGCP project 632 "Continental Crises of the Jurassic".

\section{REFERENCES}

Aberhan, M., 2002. Opening of the Hispanic Corridor and Early Jurassic bivalve biodiversity. Geological Society of London Special Publications, 194: 127-139.

Aigner, T., 1985. Storm depositional systems. Lecture Notes in Earth Sciences, 3: 1-174.

Arndorff, L., 1993. Lateral relations of deltaic palaeosols from the Lower Jurassic Rrnne Formation on the island of Bornholm, Denmark. Palaeogeography, Palaeoclimatology, Palaeoecology, 100: 235-250

Bojanowski, M.J., Jaroszewicz, E., Kosir, A., Łoziński, M., Marynowski, L., Wysocka, A., Derkowski, A., 2016. Root-related rhodochrosite and concretionary siderite formation in oxygen-deficient conditions induced by a ground-water table rise. Sedimentology, 63: 523-551.
Bromley, R.G., 1996. Trace fossils in biology, taphonomy and applications. 2nd Edition. Chapman and Hall, London.

Cantú-Chapa, A., 1998. Las trasgresiones jurásicas en México. Revista Mexicana de Ciencias Geológicas, 15: 25-37.

Carrasco-Ramírez, R.S., 2003. Los ammonites del Caloviano de la región Mixteca, Oaxaca, México. Boletín de la Sociedad Geológica Mexicana, 56: 42-55.

Damborenea, S.E., 2000. Hispanic Corridor: its evolution and the biogeography of bivalve molluscs. GeoResearch Forum, 6 369-380.

De Raaf, J.F.M., Boersma, J.R., Van Gelder, A., 1977. Wave-generated structures and sequences from a shallow marine succession, Lower Carboniferous, County Cork, Ireland. Sedimentology 24: 451-483. 
Dott, R.H.Jr., Bourgeois, J., 1982. Hummocky stratification: significance of its variable bedding sequences. Bulletin of the Geological Societyof America, 93: 663-680.

Durán-Aguilar, R.F., 2014. Sedimentología y geocronología de los lechos rojos del Jurásico, Región Norte de la Cuenca de Tlaxiaco, Tezoatlán, Oaxaca: Correlaciones y procedencia. Msc. thesis. Instituto de Geología, Universidad Nacional Autónoma de México, México D.F.

Ehrenberg, K., 1944. Ergänzende Bemerkungen zu den seinerzeit aus dem Miozän von Burgschleinitz beschriebenen Gangkernen und Bauten dekapoder Krebse. Paläontologische Zeitschrift, 23: 345-359.

Ekdale, A.A., Bromley, R.G., Pemberton, G.S., 1984. Ichnology: the use of trace fossils in sedimentology and stratigraphy. SEPM Short Course, 15: 1-317.

Embry, A., 2002. Transgressive-Regressive (T-R) Sequence Stratigraphy. 22nd Annual Gulf Coast Section SEPM Foundation Bob F. Perkins Research Conference 2002: 151-172, doi: 10.5724/gcs.02.22.0151

Erben, H.K., 1956a. El Jurásico medio y el Calloviano de México. XX Congreso Geológico Internacional, Monografía, México D.F., México.

Erben, H.K., 1956b. Estratigrafía y Paleontología del Mesozoico de la Cuenca Sedimentaria de Oaxaca y Guerrero. Especialmente del Jurásico Inferior y Medio. XX Congreso Geológico Internacional, Excursión A-12. México D.F: 11-36.

Fimmen, R.L., Richter, D.D., Vasudevan, D., Williams, M.A., West, L.T., 2008. Rhizogenic Fe-C redox cycling: a hypothetical biogeochemical mechanism that drives crustal weathering in upland soils. Biogeochemistry, 87: 127-141.

Flint, S., Aitken, J., Hampson, G., 1995. Application of sequence stratigraphy to coal-bearing coastal plain successions: implications for the UK Coal Measures. Geological Society Special Publication 82: 1-16.

Galloway, W.E., 1989. Genetic stratigraphic sequences in basin analysis i: architecture and genesis of flooding-surface bounded depositional intervals. American Association of Petroleum Geologists Bulletin, 73: 125-142.

Galloway, W.E., Hobday, D.K., 1996. Terrigenous Clastic Depositional Systems. Springer-Verlag, Berlin.

Ghibaudo, G., Grandesso, P., Massari, F., Uchman, A., 1996. Use of trace fossils in delineating sequence stratigraphic surfaces (Tertiary Venetian Basin, northeastern Italy). Palaeogeography, Palaeoclimatology, Palaeoecology, 120: 261-279.

Goldhammer, R.K., 1999. Mesozoic sequence stratigraphy and paleogeographic evolution of northeast Mexico. Geological Society of America Special Paper, 340: 1-58.

Hallam, A., 1983. Early and mid-Jurassic molluscan biogeography and the establishment of the central Atlantic seaway. Palaeogeography, Palaeoclimatology, Palaeoecology, 43:181-193.

Handford, C.R., 1985. Facies and bedding sequences in shelf-storm-deposited carbonates - Fayetteville shale and Pitkin Limestone (Mississippian), Arkansas. Journal of Sedimentary Petrology, 56: 123-137.

Harms, J.C., Southard, J.B., Spearing, D.R., Walker, R.G., 1975. Depositional environments as interpreted from primary sedimentary structures and stratification sequences. Short Course of the Society of Economic Paleontologists and Mineralogists, 2: 1-166.

Ketzer, J.M., Holz, M., Morad, S., Al.-Aasm, I.S., 2003. Sequence stratigraphic distribution of diagenetic alterations in coal-bearing, paralic sandstones: evidence from the Rio Bonito Formation (Early Permian), southern Brasil. Sedimentology, 50: 855-877.

Leckie, D.A., Krystynik, L., 1989. Is there evidence for geostrophic currents preserved in the sedimentary record of inner to middle -shelf deposits? Journal of Sedimentary Petrology, 59: 862-870

López-Ticha, D., 1985. Revisión de la estratigrafía y potencial petrolero de la Cuenca de Tlaxiaco. Asociación Mexicana Geólogos Petroleros, Boletín, 37: 49-92.

Ludvigson, G.A., Gonzalez, L.A., Metzger, R.A., Witzke, B.J., Brenner, R.L., Murillo, A.P., White, T.S., 1998. Meteoric sphaerosiderite lines and their use for paleohydrology and paleoclimatology. Geology, 26: 1039-1042.

Ludvigson, G.A., Gonzalez, L.A., Fowle, D.A., Roberts, J.A., Driese, S.G., Villarreal, M.A., Smith, J.J., Suarez, M.B., 2013. Paleoclimatic applications and modern process studies of pedogenic siderite. SEPM Special Publications, 104: 79-87.

MacEachern, J.A., Burton, J.A., 2000. Firmground Zoophycos in the Lower Cretaceous Viking Formation, Alberta: a distal expression of the Glossifungites ichnofacies. Palaios, 15: 387-398.

Martini, L.P., Johnson, D.P., 1987. Cold-climate, fluvial to paralic coal-forming environments in the Permian Collinsville coal measures, Bowen Basin, Australia. International Journal of Coal Geology, 7: 365-388.

Martini, M., Velasco-de León, P., Zepeda-Martínez, M. Lozano-Carmona, D.E., Ramírez-Calderón, M., 2017. Field guide to the Jurassic Otlaltepec and Tezoatlán Basins, southern Mexico: sedimentological and paleontological records of Puebla and Oaxaca. Boletín de la Sociedad Geológica Mexicana, 69: 691-709.

McCabe, P.J., 1984. Depositional models of coal and coal-bearing strata. International Association of Sedimentologists, Special Publication, 7: 13-42.

McCabe, P.J., Parrish, J.T., 1992. Tectonic and climatic controls on the distribution and quality of Cretaceous coals. Geological Society of America, Special Paper, 267: 1-15.

Miall, A.D., 1996. The Geology of Fluvial Deposits: Sedimentary Facies, Basin Analysis, and Petroleum Geology. Springer, Berlin, New York.

Mitta, V.V., 2018. On the geological excursions of the 10th International Congress on The Jurassic System (Mexico, 2018). In: Contributions to Current Cephalopod Research: Morphology, Systematics, Evolution, Ecology and Biostratygraphy, vol. 5., Proceeding of conference Moscow, 29-31 October, 2018 (eds. T.B. Leonova, I.S. Barskov and V.V. Mitta): 16-19. Russian Academy of Sciences, Borissiak Paleontological Institute, Moscow, PIN RAS, 2018.

Monaco, P., Caracuel, J.E., Giannetti, A., 2007. Thalassinoides and Ophiomorpha as cross-facies trace fossils of crustaceans from shallow to deep water environments: Mesozoic and Tertiary examples from Italy and Spain. Memorie della Societa Italiana di Scienze Naturali e del Museo Civico di Storia Naturale di Milano, 35: 79-82.

Morán-Zenteno, D., Caballero-Miranda, G., Silva-Romo, G., Ortega-Guerrero, B., González-Torres, E., 1993. Jurassic-Cretaceous paleogeographic evolution of the northern Mixteca terrane. southern Mexico. Geofisica Internacional, 23: 453-473.

Ochoa-Camarillo, H.R., Buitrón, B.E., Silva-Pineda, A., 1999. Redbeds of the Huayacocotla anticlinorium, state of Hidalgo, east-central Mexico. Geological Society of America Special Paper, 340: 59-68.

Pemberton, S.G., Frey, R.W., 1985. The Glossifungites ichnofacies: modern examples from the Georgia Coast, USA. Mineralogical Special Publications, 35: 237-259.

Pemberton, S.G., MacEachern, J.A., 1995. The sequence stratigraphy significance of trace fossils: examples from the Cretaceous foreland basin of Alberta, Canada. American Association of Petroleum Geologists Memoirs, 64: 429-475.

Pemberton, S.G., MacEachern, J.A., Saunders, T., 2004. Stratigraphic applications of substrate-specific ichnofacies: delineating discontinuities in the rock record. Geological Society, Special Publications, 228: 29-62.

Pervesler, P., Roetzel, R., Uchman, A., 2011. Ichnology of shallow sublittoral siliciclastics of the Burgschleinitz Formation (Lower Miocene, Eggenburgian) in the Alpine-Carpathian Foredeep (NE Austria). Austrian Journal of Earth Sciences, 104: 81-96.

Pieńkowski, G. 2004. The epicontinental Lower Jurassic of Poland. Polish Geological Institute Special Papers 12: 1-154.

Porter, S.J., Selby, D., Suzuki, K., Gröcke, D., 2013. Opening of a trans-Pangaean marine corridor during the Early Jurassic: insights from osmium isotopes across the Sinemurian-Plien- 
sbachian GSSP, Robin Hood's Bay, UK. Palaeogeography Palaeoclimatology, Palaeoecology, 375: 50-58.

Posamentier, N.W., Vail, P.R., 1988. Eustatic controls on clastic deposition II - sequence and systems tract models. Society of Economic Paleontologists and Mineralogists, Special Publication, 42: 125-154.

Postma, D., 1982. Pyrite and siderite formation in brackish and fresh water swamp sediments. American Journal of Science, 102: 1151-1183.

Reineck, H.E., Wunderlich, F., 1968. Classification and origin of flaser and lenticular bedding. Sedimentology, 11: 99-104.

Rodríquez-Tovar, F.J., Valera, F.P., López, A.P., 2007. Ichnological analysis in highresolution sequence stratigraphy: the Glossifungites ichnofacies in Triassic successions from the Betic Cordillera (southern Spain). Sedimentary Geology, 198: 293-307.

Sandoval, J., Westernmann, E.G., 1986. The Bajocian (Jurassic) Ammonite Fauna of Oaxaca, Mexico. Journal of Paleontology 60: 1220-1271.

Sarjeant, W.A.S., 1975. Plant trace fossils. In: The Study of Trace Fossils (ed. R.W. Frey): 163-179. Springer-Verlag, Berlin.

Savrda, C.H., Browning, J.V., Krawinkel, H., Hesselbo, S.P. 2001. Firmground ichnofabrics in deep-water sequence stratigraphy, Tertiary clinoform-toe deposits, New Jersey slope. Palaios, 16: 294-305.

Schieber, J., 1999. Distribution and deposition of mudstone facies in the Upper Devonian Soneya Group of New York. Journal of Sedimentary Research, 69: 909-925.

Seilacher, A., 1967. Bathymetry of trace fossils. Marine Geology, 5 : 413-428.

Shanley, K.W., McCabe, P.J., 1993. Alluvial stratigraphy in a sequence stratigraphic framework: a case history from the Upper Cretaceous of Southern Utah, USA. International Association of Sedimentology, Special Publicatio, 15: 21-56.
Sharafi, M., Ashuri, M., Mahboubi, A., Moussavi-Harami, R., 2012. Stratigraphic application of Thalassinoides ichnofabric in delineating sequence stratigraphic surfaces (Mid-Cretaceous), Kopet-Dagh Basin, northeastern Iran. Palaeoworld, 21: 202-216.

Smith, N.D., 1971. Transverse bars and braiding in the Lower Platte River, Nebraska. Geological Society American Bulletin, 82: 3407-3420.

Smith, P.L., 1983. The Pliensbachian ammonite Dayiceras dayiceroides and Early Jurassic paleogeography. Canadian Journal of Earth Sciences, 20: 86-91.

Vail, P.R., Mitchum, R.M.Jr., Todd, R.G. Widmeir, J.M., Thompson, S.lii., Sangree, J.B., Bubb, J.N. And Hatlelid, W.G., 1977. Seismic stratigraphy and global changes of sea-level. American Association of Petroleum Geologists, Memoir, 26: 49-212.

Vite-del Ángel, A.O., 2014. Estudio petrológico de la secuencia basal del grupo Tecocoyunca (sensu Jiménez-Rentería, J., 2004) en la cańada de Rosario Nuevo, Mpio. De Tezoatlán, Oax., Bachelor thesis. Instituto Politécnico Nacional, Escuela Superior de Ingeniería y Arquitectura, Unidad Ticomán.

Wetzel, A., 2008. Recent bioturbation in the deep South China Sea: a uniformitarian ichnologic approach. Palaios, 23: 601-615

Wetzel, A., Uchman, A., 1998. Biogenic sedimentary structures in mudstones - an overview. In: Shales and Mudstones I (eds. J. Schieber, W. Zimmerle and P. Sethi): 351-369. Schweizerbart, Stuttgart.

Zepeda-Martínez, M., Martini, M., Solari, L., 2018. A major provenance change in sandstones from the Tezoatlán basin, southern Mexico, controlled by Jurassic, sinistral normal motion along the Salado River fault: implications for the reconstruction of Pangea. Journal of South American Earth Science, 86: 447-460. 